\title{
Emerging targeted therapies for melanoma treatment (Review)
}

\author{
ANGELA RUSSO $^{1 *}$, BARTOLOMEA FICILI $^{1 *}$, SAVERIO CANDIDO $^{1}$, FRANCA MARIA PEZZINO ${ }^{1}$, \\ CLAUDIO GUARNERI ${ }^{2}$, ANTONIO BIONDI ${ }^{3}$, SALVATORE TRAVALI ${ }^{1}$, JAMES A. MCCUBREY ${ }^{4}$, \\ DEMETRIOS A. SPANDIDOS ${ }^{5}$ and MASSIMO LIBRA ${ }^{1}$
}

\author{
${ }^{1}$ Laboratory of Translational Oncology and Functional Genomics, Section of General Pathology and Oncology, \\ Department of Biomedical Sciences, University of Catania, I-95124 Catania; ${ }^{2}$ Department of Social Territorial Medicine, \\ Section of Dermatology, University of Messina, I-98125 Messina; ${ }^{3}$ Department of Surgery, University of Catania, \\ I-95124 Catania, Italy; ${ }^{4}$ Department of Microbiology and Immunology, Brody School of Medicine at \\ East Carolina University, Greenville, NC, USA; ${ }^{5}$ Department of Virology, Medical School, \\ University of Crete, Heraklion 71003, Crete, Greece
}

Received May 27, 2014; Accepted June 3, 2014

DOI: 10.3892/ijo.2014.2481

\begin{abstract}
Cutaneous melanoma is an aggressive cancer with a poor prognosis for patients with advanced disease. The identification of several key molecular pathways implicated in the pathogenesis of melanoma has led to the development of novel therapies for this devastating disease. In melanoma, both the Ras/Raf/MEK/ERK (MAPK) and the PI3K/AKT (AKT) signalling pathways are constitutively activated through multiple mechanisms. Targeting various effectors of these pathways with pharmacologic inhibitors may inhibit melanoma cell growth and angiogenesis. Ongoing clinical trials provide hope to improve progression-free survival of patients with advanced melanoma. This review summarizes the most relevant studies focused on the specific action of these new molecular targeted agents. Mechanisms of resistance to therapy are also discussed.
\end{abstract}

\section{Contents}

1. Introduction

2. MAPK/MEK/ERK inhibitors

3. PI3K/AKT/mTOR inhibitors

4. Immunotherapy and ipilimumab

5. Combination therapy

6. Conclusion

Correspondence to: Dr Massimo Libra, Department of Biomedical Sciences, Section of General Pathology and Oncology, Laboratory of Translational Oncology and Functional Genomics, University of Catania, Via Androne 83, I-95124 Catania, Italy

E-mail:mlibra@unict.it

*Contributed equally

Key words: melanoma, MAPK/AKT pathway, targeted therapies

\section{Introduction}

Cutaneous melanoma, is a form of aggressive cancer that develops from melanocytes. It is most common in people between 30 and 60 years of age. The highest incidence rates occurs in white-skinned peoples living at low latitudes (1). Accordingly, the association between sun exposure and melanoma have been explored. An important risk factor for melanoma is UV irradiation upon sun exposure (2). Indication of a direct UV mutagenic effect in melanoma development remains controversial as the nucleotide exchange detected in the $B-R A F$ gene (T/A) is not classically linked to UV mutagenesis signature attributable to cytidine to thymidine $(C \rightarrow T)$ transitions. As suggested, it is possible that $B-R A F$ mutations could arise from error prone replication of UV-damaged DNA (3). Melanoma is a heterogeneous disease that presents different genetic alterations and variety of histologic subtypes (4). $B-R A F$ mutations were commonly detected in cutaneous melanomas arising from intermittent sun-exposed sites (5). Accordingly, we have, recently, identified a higher frequency of $B-R A F^{\mathrm{V} 600 \mathrm{E}}$ mutation in melanoma of the trunk from indoor workers compared to outdoor workers, suggesting that this mutation may be associated with an intermittent exposure to the sun, as usually the trunk is a sun-protected body site (6).

Melanomas exhibit mutations in the Ras/Raf/mitogen activated protein kinase (MAPK) pathway. Over $50 \%$ of melanomas harbor activating mutations in $B-R A F$ gene $\left(B-R A F^{\mathrm{V} 600 \mathrm{E}}\right)$ $(7,8)$, known to play a key role in proliferation and survival of melanoma cells through activation of the MAPK pathway (9). Furthermore, this mutation causes constitutive activation of the kinase as well as insensitivity to negative feedback mechanism (10). $B-R A F^{\mathrm{V} 600 \mathrm{E}}, B-R A F^{\mathrm{V} 600 \mathrm{~K}}, B-R A F^{\mathrm{V} 600 \mathrm{R}}$ and $B-R A F^{\mathrm{V} 600 \mathrm{D}}$ mutations were detected at the frequency from 6 to $3 \%$ (7). Knowledge on the deregulation of MAPK and P3K pathways in different cancer types, including melanoma, has led to the development of specific inhibitors of their key components (11-14) (Fig. 1).

A list of current clinical trials for melanoma is available on the NCI Web site (http://www.cancer.gov/clinicaltrials). 
Table I. MAPK/AKT inhibitors and their targets.

\begin{tabular}{lll}
\hline Drug & \multicolumn{1}{c}{ Target } & Pathway \\
\hline Sorafenib (BAY43-9006) & $B-R A F, C-R A F, V E G F-R, P D G F-R$ & Ras/Raf/MEK/ERK \\
Vemurafenib (PLX-4032) & $B-R A F^{(\mathrm{V} 600 \mathrm{E}, \mathrm{V} 600 \mathrm{~K})}$ & \\
Dabrafenib (GSK 2118436) & $B-R A F^{(\mathrm{V} 600 \mathrm{E}, \mathrm{V} 600 \mathrm{~K})}$ & $\mathrm{MEK} 1 / 2$ \\
Trametinib (GSK1120212) & MEK1/2 & PI3K/AKT/mTOR \\
Selumetinib (AZD6244) & PI3K-mTOR & \\
BEZ235 & PI3K-mTOR & PTLA-4 receptor \\
GSK2126458 & PI3K & mTORC1 \\
BYL719 & mTORC1 & Anti-CTLA-4 \\
CCI-779 (Temsirolimus) & & \\
RAD001 (Everolimus) & &
\end{tabular}

For stage IV (TNM) melanoma we found a total of 281 ongoing clinical trials. Most of these studies are evaluating whether any benefits are observed after treatment with novel combination therapies or tailored therapies compared to standard treatments. In Table I the MAPK/AKT inhibitors with their targets are summarized. The prognosis for melanoma patients at early stage of the disease is $90 \%$ survival by surgical treatment. In contrast, the prognosis for advanced melanoma is restricted due to the development of drug resistance after treatment with chemotherapeutic agents (15). This review is focused on the clinical application for the treatment of melanoma with MAPK and AKT inhibitors and other novel therapies. Mechanisms of resistance for each therapy are also discussed.

\section{MAPK/MEK/ERK inhibitors}

Sorafenib. Sorafenib (BAY43-9006, Nexavar, Bayer Pharmaceuticals Corp., West Haven, CT, USA) is a potent multi-kinase inhibitor that targets also the receptor tyrosine kinase-associated angiogenesis (VEGFR-2, VEGFR-3, PDGF- $\beta$ ) and tumor progression (c-KIT, FLT-3) $(16,17)$. Sorafenib was initially developed as an inhibitor of the RAF serine/threonine kinases and administered orally in combination with carboplatin and taxol in patients with lung cancer (10).

The study of this inhibitor in xenograft models showed that sorafenib inhibited tumor cell proliferation and/or endothelial cell mediated tumor angiogenesis in several forms of human cancer (18). Sorafenib administered as monotherapy has a manageable side effect profile in phase I/II/III studies (19-21) and the most common toxic effects are hand-foot skin reaction (HFS), rash and diarrhoea (22). Sorafenib is effective in the treatment of a small percentage of melanomas that carry mutations G469E and D594G in $B-R A F$ gene expressing constitutively ERK1/2, low levels of MEK. However, it did not show significant benefit in melanoma patients harboring $B-R A F^{\mathrm{V} 600 \mathrm{E}}$ mutation (23). It was suggested that a receptor kinase upstream of Ras/Raf/MEK/ERK cascade may be targeted by sorafenib (24). This inhibitor may be administered in combination with an inhibitor of MEK in the treatment of more aggressive forms of melanoma. It may target the VEGF and other membrane receptors expressed in cancer cells, whereas the MEK inhibitor blocks the cascade which is abnormally activated by $B-R A F(25)$. The sorafenib dose (400 $\mathrm{mg}$ b.i.d) is administered in combination with standard chemotherapy, such as dacarbazine, in patients with advanced melanoma because it has few side effects as a single agent, indeed the response rate was $21 \%$ with a median time from treatment initiation of 2.3 months (26). Although this combination does not cause toxic effects and shows antitumor activity, it is not applied in clinical practice because selective inhibitors of $B-R A F$ are more effective in the treatment of malignant melanoma (27).

Vemurafenib. Vemurafenib (Zelboraf, Plexxikon/Roche) was approved first by the FDA in USA, in August 2011, for the treatment of patients with metastatic melanoma with $B-R A F^{\mathrm{V} 600 \mathrm{E}}$ mutation and then in Europe (15). Vemurafenib (PLX4032) is a potent oral drug that inhibits the kinase domain of the most common mutation of $B-R A F\left(B-R A F^{\mathrm{V} 600 \mathrm{E}}\right)$, decreasing cell proliferation through the phosphorylation of ERK and cyclin D1 $(28,29)$, but it does not have antitumor effects against cells with $B-R A F^{\mathrm{WT}}(30,31)$.

The pharmacodynamic analysis reported that the activity of vemurafenib was characterized as exposure-dependent tumor response corresponding with percentage of inhibition of MEK and ERK phosphorylation. Additionally, the relationship between dose exposure and response suggests that melanoma regression was found to correlate with $>90 \%$ inhibition of ERK phosphorylation (32).

Patients with advanced melanoma and $B-R A F$ mutations showed in phase I and II clinical trials of vemurafenib an antitumor response in more than $50 \%$ of the patients. A phase III study comparing vemurafenib with dacarbazine in previously untreated patients revealed an overall survival rate of $84 \%$ among patients treated with vemurafenib and $64 \%$ in the other group of patients. Vemurafenib was associated with a relative reduction of $63 \%$ in the risk of death and $74 \%$ in the risk of either death or disease progression, as compared with dacarbazine (30). The maximum tolerated dose is $960 \mathrm{mg}$ twice 


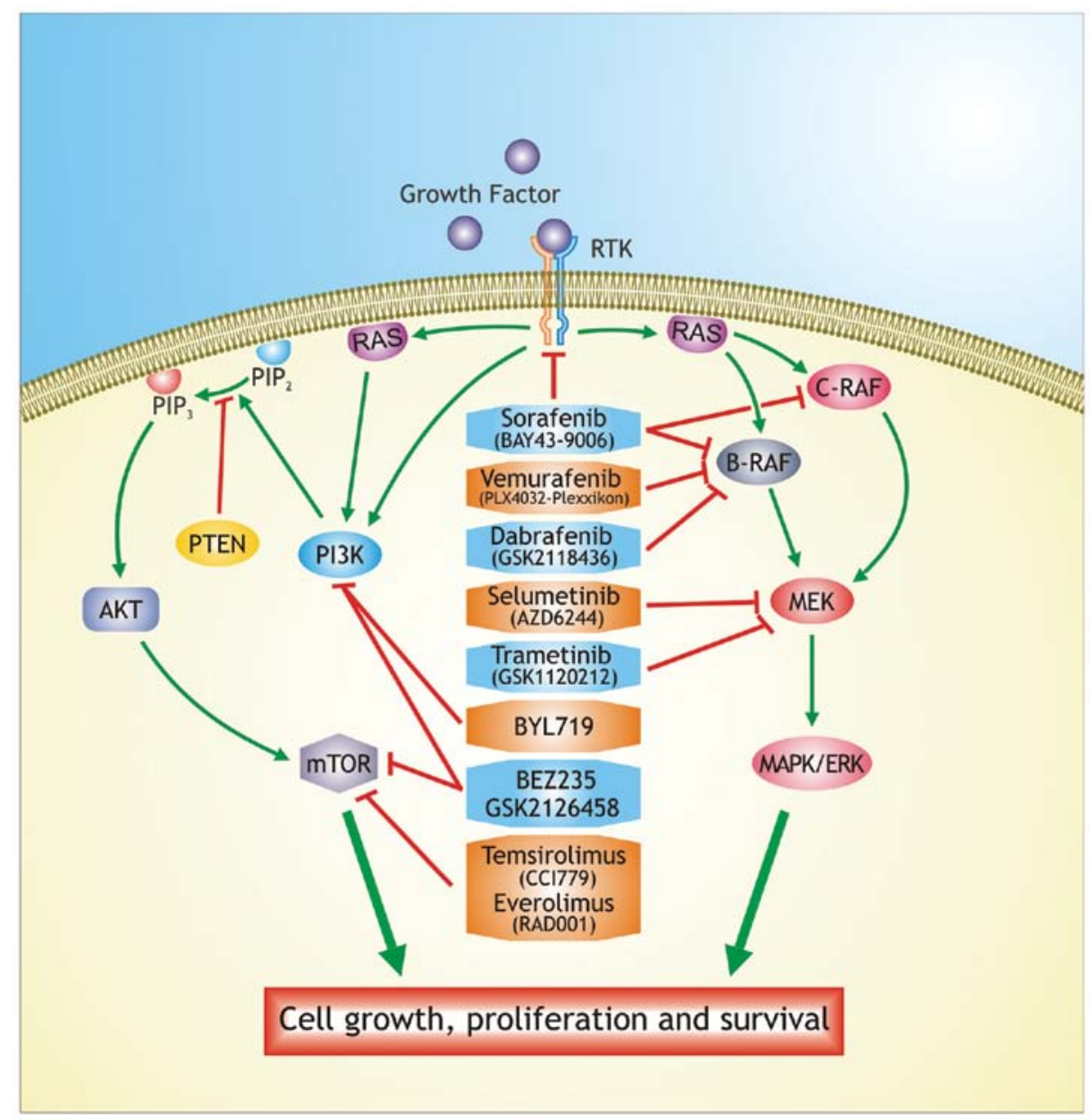

Figure 1. Raf/MEK/ERK and PI3K/AKT pathways and mechanism of action of their inhibitors in melanoma.

daily, showing positive tumor responses. Patients who had received previous treatment for melanoma with $B-R A F^{\mathrm{V} 600 \mathrm{E}}$ mutation showed a response rate of $53 \%$, with a median duration of response of 6.7 months (33). In addition, vemurafenib causes acanthopapillomas, keratoacanthomas and cutaneous squamous cell carcinomas in the early treatment $(34,35)$. Vemurafenib demonstrates an exceptional response in melanoma patients with $B-R A F^{\mathrm{V} 600 \mathrm{E}}$ mutation and its introduction represented a step forward in the treatment of this disease (36). Despite the encouraging results obtained, the duration of response is limited because tumors quickly develop resistance via molecular alterations in other pathway components (37). Drug resistance is a common problem associated with treatment with chemotherapeutic agents. To evaluate the mechanisms of resistance is essential to understand the adaptability of tumor cells and the multiple mechanisms that lead to drug resistance $(14,38)$. Resistance mechanisms can be divided into MAPK-dependent and MAPK-independent pathways.

MAPK-dependent resistance mechanisms lead to reactivation of ERK, changes in $B-R A F$, such as amplification of mutant $B-R A F$ or truncations in the $\mathrm{B}-\mathrm{Raf}$ protein through alternate splicing leading to increased dimerization and resultant kinase activity (39). In addition, resistance is caused by secondary mutations in the MAPK pathway immediately upstream at the level of $N-R A S$ and downstream at the level of $\mathrm{MEK}$, which render the kinase insensitive to the inhibitor (40).
MEK1/2 are phosphorylated and activated by $B-R A F$; mutation in MEK1 (P124L) was identified to be responsible for cellular resistance to PLX 4032 (41). The resistance to treatment occurs after an initial response (42). The potent antitumor effect of vemurafenib is mediated through inhibition of the oncogenic MAPK signaling. Clinical trials are currently underway in the treatment of advanced melanoma to test the efficacy of vemurafenib with immunomodulatory agents, such as ipilimumab, and in combination with MEK inhibitors, such as GDC-0973 (43).

Dabrafenib. Dabrafenib (GSK2118436) is a reversible ATP-competitive inhibitor that selectively inhibits $B-R A F$. It is similar to vemurafenib concerning the mechanism of action, pharmacodynamics, timing of responses and development of resistance, but it presents a shorter half-life (44). Dabrafenib is efficient in about $50-70 \%$ of patients with $B-R A F^{\mathrm{V} 600 \mathrm{E}}$ or $B-R A F^{\mathrm{V} 600 \mathrm{~K}}$ mutations $(45,46)$.

A phase I/II study of dabrafenib established a dose of $150 \mathrm{mg}$ twice daily and reported positive responses in about $50 \%$ of the patients with advanced melanoma and a median progression-free survival of 6-3 months (47). The most common cutaneous side effects were hyperkeratosis, papillomas and palmar-plantar erythrodysaesthesia; other side effects were pyrexia, fatigue, headache and arthralgia, which together necessitated dose reductions (48). 
In a phase III study, comparing dabrafenib vs. dacarbazine, it has been demonstrated that the response rates were 53 vs. $19 \%$ and PFS 5.3 vs. 2.7, although the trial allowed crossover and was not powered to detect an overall survival benefit $(49,50)$. The low rate of survival benefit was partly due to the obligatory crossover to dabrafenib at progression in patients randomly assigned to dacarbazine (29).

MEK inhibitors. MEK proteins belong to a family of enzymes, that selectively phosphorylate serine/threonine and tyrosine residues within the activation loop of their specific MAP kinase substrates. MEK1 and MEK2 display a similar structural organization, are closely related and they participate in the Ras/Raf/MEK/ERK signal transduction cascade $(51,52)$.

Several MEK inhibitors have been tested in clinical trials. Selumetinib (AZD6244), is an oral small molecule that inhibits MEK1/2 and has been tested clinically in a randomize phase II trial in patients with $B-R A F$ mutated melanoma (53). In a phase III study, only trametinib (known as GSK1120212 or JTP-74057), a selective oral inhibitor of MEK1 and 2, has been demonstrated to have impact on clinical efficacy $(54,55)$. Trametenib causes a block of the protein MEK, and is correlated with improved PFS in patients carrying $B-R A F^{\mathrm{V} 600 \mathrm{E} / \mathrm{K}}$ mutations (56).

Previous studies showed that trametinib inhibits cell growth by the inhibition of pERK $1 / 2$, inducing cell cycle arrest in cell lines with mutant $B-R A F$ and $R A S$. This shows its potent antitumor activity when administered daily for 14 days (57-59). In a phase III trial (METRIC), trametinib was compared with dacarbazine in patients with $B-R A F$ mutations (60), observing an improvement in median survival of $81 \mathrm{vs.} 67 \%$ and PFS of 4.8 vs. 1.5 months, with an objective response rate about $25 \%$ (61). Administration of trametinib, as monotherapy, results in a low activity in patients previously treated with B-RAF inhibitors. Resistance to B-RAF inhibitors may be also associated with resistance to MEK inhibitors. In patients treated with trametinib the most common toxic effects included skin rash, diarrhea, edema, hypertension and fatigue (62). Trametinib compared with chemotherapy showed a significant improvement in progression-free and overall survival in patients with advanced and/or metastatic melanoma (60).

\section{PI3K/AKT/mTOR inhibitors}

PI3K/AKT/mTOR pathway is one of the most frequently dysregulated pathway in human cancer. The most frequent causes of changes in this pathway include mutation or increased gene copy numbers of PIK $3 C A$ or other PI3K isoforms, loss of expression of the pathway suppressors (for example, PTEN) or hyperactivation of RTKs through receptor overexpression or activating mutations (63-66). Hot spot mutations of the PIK3CA gene include E542K, E545K and H1047R. These mutations are oncogenic per se, as they can induce the generation of tumors in several preclinical models without other molecular aberrations (67-69).

The PI3K/AKT/mTOR and RAS/RAF/MEK/ERK pathways interact at multiple points, resulting in cross-activation, cross-inhibition, pathway convergence and these observations have driven the development of small molecule inhibitors that target various nodes of both pathways (70).
Recent studies have revealed that PI3K signalling is deregulated in a high proportion of melanomas (11). Indeed, PTEN is deleted and the downstream $A K T$ gene is amplified in about $45 \%$ of melanomas. These alterations cause an overexpression of AKT3, an isoform of AKT (71). Increased phospho-AKT expression in melanoma is associated with tumor progression and shorter survival (72). The study of genomic alterations in primary melanomas showed that tumors with $B-R A F$ mutations had few copies of PTEN, suggesting that dual activation of the PI3K-AKT and MAPK pathways are important events in melanoma development (73).

The research on PI3K inhibitors is expanding in order to find more selective compounds, such as isoform-specific PI3K inhibitors (74).

Advanced studies led to the development of inhibitors of PI3K which selectively target only the catalytic sites (75). The new PI3Ka isoform-specific inhibitors gave an effective response in cell lines that present PIK3CA mutations $(76,77)$. In addition, one of these compounds, BYL719, has revealed that besides PIK3CA mutations, the presence of PI3KCA amplification correlated with higher drug sensitivity, while $B-R A F$ and PTEN mutations were correlated with resistance (74).

The PI3K inhibitors, GSK2126458 and BEZ235, were evaluated in vitro in combination with MEK inhibitors, showing enhanced cell growth inhibition. Monotherapy with inhibitors of PI3K did not show advantage in clinical response, suggesting their use in combination with other drugs (78). The low efficacy of the monotherapy treatments is due to the interaction between the parallel PI3K/AKT/mTOR and RAS/RAF/MEK/ERK pathways and the resistance to therapy can be induced by overexpression or overactivation of PDGFR- $\beta$ or IGF1R (25). To overcome the resistance mechanisms, dual inhibition of both pathways with combined therapy may be appropriate (14). PI3K and MEK inhibitor combinations are well tolerated and can be administered at therapeutic doses; however, additional studies are required to establish the precise tumor properties that will better respond to therapy (38). Rapamycin is a mTORC1 blocker of the first generation, while everolimus (RAD001) and temsirolimus (CCI779) are considered agents of second generation, which allosterically inhibit the mTOR complex $(79,80)$; these agents do not have high specificity in targeting melanoma tumor cells (73).

\section{Immunotherapy and ipilimumab}

New therapeutic approaches involve the use of immunotherapy for the treatment of cancer. Immunotherapy is based on increasing the immune defenses to eliminate the cancer cells to gain chemotherapeutic effect, and aiming to arrest the cell cycle inducing apoptosis (81).

Immunotherapy may be used for tumors because they express tumor associated antigens $(82,83)$; melanoma lesions often contain a high number of infiltrative T-cells specific to melanocyte tumor-associated antigens such as MART1, gp100 and tyrosinase (84). An approach to eliminate the melanoma cells is to increase the natural function of these cytotoxic $\mathrm{T}$ lymphocytes (CTL) (85).

Cytotoxic T lymphocyte-associated antigen 4 (CTLA-4) is an immunoglobin-like molecule found primarily on $\mathrm{CD}^{+}$ 
or $\mathrm{CD} 8^{+} \mathrm{T}$ lymphocytes and high levels of CTLA- 4 are also important in maintaining certain subsets of T-regulatory cells. CTLA-4 is an 'immune checkpoint' that downregulates pathways of T-cell activation and prevents autoimmunity, for this purpose it has become an attractive target for immunotherapy (86).

The first immunotherapy to be approved by the Food and Drug Administration (FDA) for treatment of advanced melanoma was interleukin-2 (IL-2) but, like dacarbazine, response rates were low even at high-doses of treatment (87). Its use in clinical practice is limited by the severe toxic side-effects (88-90).

Ipilimumab is a recombinant, human monoclonal antibody that binds to CTLA- 4 and blocks the interaction of CTLA-4 with its ligands, CD80 and CD86. This immunotherapeutic augments the antitumor T-cell response resulting in uncontrolled T-cell proliferation and for this reason is associated with a substantial risk of immune-related adverse reactions $(91,92)$. Ipilimumab acts by an indirect mechanism through T-cell mediated antitumor immune responses. The most common severe immune-mediated adverse reactions are enterocolitis, hepatitis, dermatitis, neuropathy and endocrinopathy; these reactions can occur both during the treatment, or weeks or months after discontinuation of treatment $(93,94)$.

Ipilimumab was approved, as monotherapy at $3 \mathrm{mg} / \mathrm{kg}$, in the European Union in 2011 for pretreated adult patients with advanced (unresectable or metastatic) melanoma and in the United States for both first- and second-line treatment for advanced melanoma $(95,96)$. In a clinical study, untreated patients with advanced melanoma received a higher dose of ipilimumab with or without dacarbazine or dacarbazine plus placebo. Patients treated with dacarbazine and ipilimumab showed a significant increase of the overall survival rate compared with those treated with dacarbazine plus placebo (29). The treatment with ipilimumab in advanced melanoma patients was also considered in concomitance with the experimental vaccine glycoprotein 100 (gp100) (97). Patients with advanced melanoma stage III or IV were included in this study. Pre-treated patients were randomized for the administration of ipilimumab alone or in combination with gp100 or gp100 alone. It was shown that the combination with ipilimumab and gp100 did not improve survival when compared with ipilimumab alone, suggesting that ipilimumab remains the treatment with most efficacy for advanced melanoma (98).

Besides ipilimumab, also nivolumab, a monoclonal antibody directed against the PD-1 receptor or its ligand (PD-L1) has been reported (97). PD-1 receptor acts as an inhibitory receptor of T cells similar to CTLA-4. In an initial phase I study of a monoclonal antibody binding the PD-1 receptor, in patients previously treated, tumor responses were recorded in 26 of 94 (28\%) (99). Nivolumab has been administered as monotherapy; most recent data suggest that nivolumab and ipilimumab can be administered concomitantly with a manageable safety profile (100). Immunotherapy is becoming an important support to melanoma treatment (101).

\section{Combination therapy}

Resistance to therapeutic agents, both chemical or biological agents, remains the main problem in the management of the therapy in melanoma. Combination of B-RAF inhibitors with MEK inhibitors has been evaluated to improve the disease-free survival. This combination reduces the skin toxicities and may also enhance the antitumoral effects by synergistically suppressing ERK pathways activity (102).

In patients who have developed resistance to vemurafenib, the combination of dabrafenib and trametinib showed $76 \%$ of clinical response compared with that obtained with the treatment of dabrafenib as single agent (54\%) (41).

In a phase I/II trial, the combination of dabrafenib and trametinib was effective in patients with $B-R A F^{\mathrm{V} 600 \mathrm{E}}$ mutated metastatic melanoma and numerous clinical trials are in progress to test other combinations of B-RAF and MEK inhibitors $(103,104)$. In a phase I study the effectiveness of vemurafenib was tested in combination with an inhibitor of MEK showing a tumor reduction in melanoma patients, while in a phase III trial vemurafenib alone was compared with vemurafenib in combination with MEK inhibitor (36). Several clinical studies are still evaluating the combination of PI3K and MEK inhibitors in a variety of cancers. This combined therapy may be able to overcome the resistance mechanisms leading to apoptosis. These combinations appear well tolerated and can be administered as therapeutic doses (80).

The approval of ipilimumab represents a further treatment option for melanoma patients. The National Comprehensive Cancer Network (NCCN) now lists ipilimumab and vemurafenib among the small number of preferred systemic regimens for treating advanced and metastatic melanoma (105). The combination of vemurafenib with immunotherapy could overcome the resistance mechanisms because immunotherapy drugs have low response rates but relatively long durations of response in a large subset of responding patients, by contrast, B-RAF inhibitors have high initial response rates but rarely produce long-term durable responses $(95,106)$. Ipilimumab targets the tumors indirectly by activation of the immune system therefore it is likely to be efficacious in melanoma patients with and without the $B-R A F^{\mathrm{V} 600 \mathrm{E}}$ mutation (100).

Some clinical trials have shown that MAPK pathway inhibition with a selective inhibitor of $B-R A F^{\mathrm{V} 600 \mathrm{E}}$ increase expression of melanoma-derived antigens by the tumor and increased the recognition of melanoma cells by antigen-specific $\mathrm{T}$ cells and, selective inhibition did not have deleterious effects on $\mathrm{T}$ cell proliferation or function $(100,107)$.

B-RAF inhibitor treatment led to increased number of tumor infiltrating lymphocytes in tumor biopsies obtained 10-14 days after treatment initiation. This increase was associated with a reduction in tumor size and an increase in necrosis in on-treatment biopsies $(108,109)$.

These results suggested that at least a subset of patients might be able to receive treatment with curative intent with interleukin-2 or ipilimumab without compromising their ability to benefit from B-RAF inhibitor treatment if they fail to achieve a durable response (106).

Studies that combine B-RAF inhibitors with immunotherapy are in progress and offer opportunities to further improve outcomes for patients with advanced B-RAF V600E mutant melanoma.

Finally, the effects of the new nitric oxide (NO) donating compound (S,R)-3-phenyl-4,5-dihydro-5-isoxazole acetic acid-nitric oxide (GIT-27NO) on the A375 human mela- 
noma cell line were investigated by our group. The capacity of GIT-27NO to induce p53-mediated apoptosis in A375 melanoma cells suggests that GIT-27NO may have a potential therapeutic use in the clinical setting $(110,111)$.

\section{Conclusion}

Cancer research is converging on understanding the roles of signal transduction pathways in drug resistance and sensitivity. Targeting various effectors of these pathways with pharmacologic inhibitors may arrest melanoma cell proliferation. This review pays attention on the clinical application of both Raf/ MEK/ERK and PI3K/AKT/mTOR pathway inhibitors as novel treatment strategy for melanoma. Furthermore, we described how alterations of molecular pathways, involved in melanoma development, interact with each other resulting in response to therapy and/or chemoresistance. The use of MAPK and AKT inhibitors for the treatment of melanoma indicates that the response rate of these new molecular targeted agents is higher compared to the standard chemotherapy. However, additional studies are needed to better define the mechanisms of resistance to these novel biological therapies.

\section{References}

1. Bataille V, Winnett A, Sasieni P, Newton Bishop JA and Cuzick J: Exposure to the sun and sunbeds and the risk of cutaneous melanoma in the UK: a case-control study. Eur J Cancer 40: 429-435, 2004

2. Hodis E, Watson IR, Kryukov GV, Arold ST, Imielinski M, Theurillat JP, Nickerson E, Auclair D, Li L, Place C, Dicara D, Ramos AH, Lawrence MS, Cibulskis K, Sivachenko A, Voet D, Saksena G, Stransky N, Onofrio RC, Winckler W, Ardlie K, Wagle N, Wargo J, Chong K, Morton DL, Stemke-Hale K, Chen G, Noble M, Meyerson M, Ladbury JE, Davies MA, Gershenwald JE, Wagner SN, Hoon DS, Schadendorf D, Lander ES, Gabriel SB, Getz G, Garraway LA and Chin L: A landscape of driver mutations in melanoma. Cell 150: 251-263, 2012.

3. Thomas NE, Berwick M and Cordeiro-Stone M: Could BRAF mutations in melanocytic lesions arise from DNA damage induced by ultraviolet radiation? J Invest Dermatol 126: 1693-1696, 2006.

4. Thomas NE, Edmiston SN, Alexander A, Millikan RC, Groben PA, Hao H, Tolbert D, Berwick M, Busam K, Begg CB, Mattingly D, Ollila DW, Tse CK, Hummer A, Lee-Taylor J and Conway K: Number of nevi and early-life ambient UV exposure are associated with BRAF-mutant melanoma. Cancer Epidemiol Biomarkers Prev 16: 991-997, 2007.

5. Venesio T, Chiorino G, Balsamo A, Zaccagna A, Petti C, Scatolini M, Pisacane A, Sarotto I, Picciotto F and Risio M: In melanocytic lesions the fraction of $\mathrm{BRAF}^{\mathrm{V} 600 \mathrm{E}}$ alleles is associated with sun exposure but unrelated to ERK phosphorylation. Mod Pathol 21: 716-726, 2008.

6. Candido S, Rapisarda V, Marconi A, Malaponte G, Bevelacqua V, Gangemi P, Scalisi A, McCubrey JA, Maestro R, Spandidos DA, Fenga $\mathrm{C}$ and Libra $\mathrm{M}$ : Analysis of the $B-R A F^{\mathrm{V} 600 \mathrm{E}}$ mutation in cutaneous melanoma patients with occupational sun exposure. Oncol Rep 31: 1079-1082, 2014.

7. Davies H, Bignell GR, Cox C, Stephens P, Edkins S, Clegg S, Teague J, Woffendin H, Garnett MJ, Bottomley W, Davis N, Dicks E, Ewing R, Floyd Y, Gray K, Hall S, Hawes R, Hughes J, Kosmidou V, Menzies A, Mould C, Parker A, Stevens C, Watt S, Hooper S, Wilson R, Jayatilake H, Gusterson BA, Cooper C, Shipley J, Hargrave D, Pritchard-Jones K, Maitland N, ChenevixTrench G, Riggins GJ, Bigner DD, Palmieri G, Cossu A, Flanagan A, Nicholson A, Ho JW, Leung SY, Yuen ST, Weber BL, Seigler HF, Darrow TL, Paterson H, Marais R, Marshall CJ, Wooster R, Stratton MR and Futreal PA: Mutations of the BRAF gene in human cancer. Nature 417: 949-954, 2002.

8. Libra M, Malaponte G, Navolanic PM, Gangemi P, Bevelacqua V, Proietti L, Bruni B, Stivala F, Mazzarino MC, Travali S and McCubrey JA: Analysis of BRAF mutation in primary and metastatic melanoma. Cell Cycle 4: 1382-1384, 2005.
9. Garnett MJ and Marais R: Guilty as charged: B-RAF is a human oncogene. Cancer Cell 6: 313-319, 2004.

10. Ascierto PA, Kirkwood JM, Grob J, Simeone E, Grimaldi AM, Maio M, Palmieri G, Testori A, Marincola FM and Mozzillo N: The role of BRAF V600 mutation in melanoma. J Transl Med 10: 85, 2012.

11. Chen B, Tardell C, Higgins B, Packman K, Boylan JF and Niu H: BRAFV600E negatively regulates the AKT pathway in melanoma cell lines. PLoS One 7: e42598, 2012.

12. Vredeveld LC, Possik PA, Smit MA, Meissl K, Michaloglou C, Horlings HM, Ajouaou A, Kortman PC, Dankort D, McMahon M, Mooi WJ and Peeper DS: Abrogation of BRAFV600E-induced senescence by PI3K pathway activation contributes to melanomagenesis. Genes Dev 26: 1055-1069, 2012.

13. Lipkin G: Plasticity of the cancer cell: implications for epigenetic control of melanoma and other malignancies. J Invest Dermatol 128: 2152-2155, 2008

14. Villanueva J, Adina V, Lee JT, Somasundaram R, FukunagaKalabis M,Cipolla AK, Wubbenhorst B, Xu X, Gimotty PA, KeeD, Santiago-Walker AE, Letrero R, D'Andrea K, Pushparajan A, Hayden JE, Kimberly BD, Laquerre S, McArthur GA, Sosman JA, Nathanson KL and Herlyn M: Acquired resistance to BRAF inhibitors mediated by a RAF kinase switch in melanoma can be overcome by co-targeting MEK and IGF-1R/PI3K. Cancer Cell 18: 683-695, 2010.

15. Viola JR, Rafael DF, Wagner E, Besch R and Hindawi MO: Gene therapy for advanced melanoma: selective targeting and therapeutic nucleic acids. J Drug Deliv 2013: 897348, 2013.

16. Wilhelm SM, Adnane L, Newell P, Villanueva A, Llovet JM and Lynch M: Preclinical overview of sorafenib, a multikinase inhibitor that targets both Raf and VEGF and PDGF receptor tyrosine kinase signaling. Mol Cancer Ther 7: 3129-3140, 2008.

17. Karasarides M, Chiloeches A, Hayward R, Niculescu-Duvaz D, Scanlon I, Friedlos F, Ogilvie L, Hedley D, Martin J, Marshall CJ, Springer CJ and Marais R: B-RAF is a therapeutic target in melanoma. Oncogene 23: 6292-6298, 2004.

18. Wilhelm SM, Carter C, Tang L, Wilkie D, McNabola A, Rong H, Chen C, Zhang X, Vincent P, McHugh M, Cao Y, Shujath J, Gawlak S, Eveleigh D, Rowley BL, Adnane L, Lynch M, Auclair D, Taylor I, Gedrich R, Voznesensky A, Riedl B, Post LE, Bollag G and Trail PA: BAY 43-9006 exhibits broad spectrum oral antitumor activity and targets the RAF/MEK/ERK pathway and receptor tyrosine kinases involved in tumor progression and angiogenesis. Cancer Res 64: 7099-7109, 2004.

19. Strumberg D, Awada A, Piccart P, Hirte H, Moore M, Clark J, Lenz HJ, Lathia C, Schwartz B and Humphrey R: Final report of the phase I clinical program of the novel raf kinase inhibitor BAY 43-9006 in patients with refractory solid tumors. J Clin Oncol 22: 203, 2003.

20. Strumberg D: Preclinical and clinical development of the oral multikinase inhibitor sorafenib in cancer treatment. Drugs Today 41: 773-784, 2005.

21. Awada A, Hendlisz A, Gil T, Bartholomeus S, Mano M, de Valeriola D, Strumberg D, Brendel E, Haase CG, Schwartz B and Piccart M: Phase I safety and pharmacokinetics of BAY 43-9006 administered for 21 days on/7 days off in patients with advanced, refractory solid tumours. Br J Cancer 92: 1855-1861, 2005.

22. Eisen T, Ahmad T, Flaherty KT, Gore M, Kaye S, Marais R, Gibbens I, Hackett S, James M, Schuchter LM, Nathanson KL, Xia C, Simantov R, Schwartz B, Poulin-Costello M, O'Dwyer PJ and Ratain MJ: Sorafenib in advanced melanoma: a Phase II randomised discontinuation trial analysis. Br J Cancer 95: 581-586, 2006.

23. Chakraborty R, Wieland $\mathrm{CN}$ and Comfere N: Molecular targeted therapies in metastatic melanoma. Pharmgenomics Pers Med 6: 49-56, 2013.

24. McCubrey JA, Steelman LS, Chappell WH, Abrams SL, Montalto G, Cervello M, Nicoletti F, Fagone P, Malaponte G, Mazzarino MC, Candido S, Libra M, Bäsecke J, Mijatovic S, Maksimovic-Ivanic D, Milella M, Tafuri A, Cocco L,Evangelisti C, Chiarini F and Martelli AM: Mutations and deregulation of Ras/ Raf/MEK/ERK and PI3K/PTEN/Akt/mTOR cascades which alter therapy response. Oncotarget 3: 954-987, 2012.

25. McCubrey JA, Steelman LS, Chappell WH, Abrams SL, Franklin RA, Montalto G, Cervello M, Libra M, Candido S, Malaponte G, Mazzarino MC, Fagone P, Nicoletti F, Bäsecke J, Mijatovic S, Maksimovic-Ivanic D, Milella M, Tafuri A, Chiarini F, Evangelisti C, Cocco L and Martelli AM: Ras/Raf/ MEK/ERK and PI3K/PTEN/Akt/mTOR cascade inhibitors: how mutations can result in therapy resistance and how to overcome resistance. Oncotarget 3: 1068-1111, 2012. 
26. Pecuchet N, Lebbe C, Mir O, Billemont B, Blanchet B, Franck N, Viguier M, Coriat R, Tod M, Avril MF and Goldwasser F: Sorafenib in advanced melanoma: a critical role for pharmacokinetics? Br J Cancer 107: 455-461, 2012.

27. Eisen T, Marais R, Affolter A, Lorigan P, Robert C, Corrie P, Ottensmeier C, Chevreau C, Chao D, Nathan PD, Jouary T, Harries M, Negrier S, Montegriffo E, Ahmad T, Gibbens I James MG, Strauss UP, Prendergast S and Gore ME: Sorafenib and dacarbazine as first-line therapy for advanced melanoma: phase I and open-label phase II studies. Br J Cancer 105: 353-359, 2011

28. Tsai J, Lee JT, Wang W, Zhang J, Cho H, Mamo S, Bremer R, Gillette S, Kong J, Haass NK, Sproesser K, Li L, Smalley KS, Fong D, Zhu YL, Marimuthu A, Nguyen H, Lam B, Liu J, Cheung I, Rice J, Suzuki Y, Luu C, Settachatgul C, Shellooe R, Cantwell J, Kim SH, Schlessinger J, Zhang KY, West BL, Powell B, Habets G, Zhang C, Ibrahim PN, Hirth P, Artis DR, Herlyn M and Bollag G: Discovery of a selective inhibitor of oncogenic B-Raf kinase with potent antimelanoma activity. Proc Natl Acad Sci USA 105: 3041-3046, 2008

29. Jang S and Atkins MB: Which drug, and when, for patients with BRAF-mutant melanoma? Lancet Oncol 14: 60-69, 2013.

30. Chapman PB, Hauschild A, Robert C, Haanen JB, Ascierto P, Larkin J, Dummer R, Garbe C, Testori A, Maio M, Hogg D, Lorigan P, Lebbe C, Jouary T, Schadendorf D, Ribas A, O'Day SJ, Sosman JA, Kirkwood JM, Eggermont AM, Dreno B, Nolop K, Li J, Nelson B, Hou J, Lee RJ, Flaherty KT and McArthur GA: Improved survival with vemurafenib in melanoma with BRAF V600E mutation. N Engl J Med 364: 2507-2516, 2011.

31. Joseph EW, Pratilas CA, Poulikakos PI, Tadi M, Wang W, Taylor BS, Halilovic E, Persaud Y, Xing F, Viale A, Tsai J, Chapman PB, Bollag G, Solit DB and Rosen N: The RAF inhibitor PLX4032 inhibits ERK signaling and tumor cell proliferation in a V600E BRAF-selective manner. Proc Natl Acad Sci USA 107: 14903-14908, 2010.

32. Bollag G, Hirth P, Tsai J, Zhang J, Ibrahim PN, Cho H, Spevak W, Zhang C, Zhang Y, Habets G, Burton EA, Wong B, Tsang G, West BL, Powell B, Shellooe R, Marimuthu A, Nguyen H, Zhang KY, Artis DR, Schlessinger J, Su F, Higgins B, Iyer R, D'Andrea K, Koehler A, Stumm M, Lin PS, Lee RJ, Grippo J, Puzanov I, Kim KB, Ribas A, McArthur GA, Sosman JA, Chapman PB, Flaherty KT, Xu X, Nathanson KL and Nolop K: Clinical efficacy of a RAF inhibitor needs broad target blockade in BRAF-mutant melanoma. Nature 467: 596-599, 2010.

33. Sosman JA, Kim KB, Schuchter L, Gonzalez R, Pavlick AC, Weber JS, McArthur GA, Hutson TE, Moschos SJ, Flaherty KT, Hersey P, Kefford R, Lawrence D, Puzanov I, Lewis KD, Amaravadi RK, Chmielowski B, Lawrence HJ, Shyr Y, Ye F, Li J, Nolop KB, Lee RJ, Joe AK and Ribas A: Survival in BRAF V600-mutant advanced melanoma treated with vemurafenib. N Engl J Med 366: 707-714, 2012.

34. Oberholzer PA, Kee D, Dziunycz P, Sucker A, Kamsukom N, Jones R, Roden C, Chalk CJ, Ardlie K, Palescandolo E, Piris A, MacConaill LE, Robert C, Hofbauer GF, McArthur GA, Schadendorf D and Garraway LA: RAS mutations are associated with the development of cutaneous squamous cell tumors in patients treated with RAF inhibitors. J Clin Oncol 30: 316-321, 2012.

35. Su F, Viros A, Milagre C, Trunzer K, Bollag G, Spleiss O, Reis-Filho JS, Kong X, Koya RC, Flaherty KT, Chapman PB, Kim MJ, Hayward R, Martin M, Yang H, Wang Q, Hilton H, Hang JS, Noe J, Lambros M, Geyer F, Dhomen N, NiculescuDuvaz I, Zambon A, Niculescu-Duvaz D, Preece N, Robert L, Otte NJ, Mok S, Kee D, Ma Y, Zhang C, Habets G, Burton EA, Wong B, Nguyen H, Kockx M, Andries L, Lestini B, Nolop KB, Lee RJ, Joe AK, Troy JL, Gonzalez R, Hutson TE, Puzanov I, Chmielowski B, Springer CJ, McArthur GA, Sosman JA, Lo RS, Ribas A and Marais R: RAS mutations in cutaneous squamouscell carcinomas in patients treated with BRAF inhibitors. N Engl J Med 366: 207-215, 2012

36. Flaherty KT, Puzanov I, Kim KB, Ribas A, McArthur GA Sosman JA, O'Dwyer PJ, Lee RJ, Grippo JF, Nolop K and Chapman PB: Inhibition of mutated, activated BRAF in metastatic melanoma. N Engl J Med 363: 809-819, 2010.

37. Corcoran RB, Settleman J and Engelman JA: Potential therapeutic strategies to overcome acquired resistance to BRAF or MEK inhibitors in BRAF mutant cancers. Oncotarget 2: 336-346, 2011.

38. McCubrey JA, Steelman LS, Kempf CR, Chappell WH, Abrams SL, Stivala F, Malaponte G, Nicoletti F, Libra M, Basecke J, Maksimovic-Ivanic D, Mijatovic S, Montalto G, Cervello M, Cocco L and Martelli AM: Therapeutic resistance resulting from mutations in Raf/MEK/ERK and PI3K/PTEN/Akt/mTOR signaling pathways. J Cell Physiol 226: 2762-2781, 2011.
39. Shao Y and Aplin AE: Akt3-mediated resistance to apoptosis in B-RAF-targeted melanoma cells. Cancer Res 70: 6670-6681, 2010.

40. Emery CM, Vijayendrana KG, Zipserc MC, Sawyera AM, Niua L, Kima JJ, Hattona C, Choprad R, Oberholzera PA, Karpovac MB, MacConailla LE, Zhangf J, Grayf NS, Sellersd WR, Dummerc R and Garrawaya LA: MEK1 mutations confer resistance to MEK and B-RAF inhibition. Proc Natl Acad Sci USA 106: 20411-20416, 2009.

41. Greger JG, Eastman SD, Zhang V, Bleam MR, Hughes AM, Smitheman KN, Dickerson SH, Laquerre SG, Liu L and Gilmer TM: Combinations of BRAF, MEK, and PI3K/mTOR inhibitors overcome acquired resistance to the BRAF inhibitor GSK2118436 dabrafenib, mediated by NRAS or MEK mutations. Mol Cancer Ther 11: 909-920, 2012.

42. Aplin AE, Kaplan FM and Shao Y: Mechanisms of resistance to RAF inhibitors in melanoma. J Invest Dermatol 131: 1817-1820, 2011.

43. Trunzer K, Pavlick AC, Schuchter L, Gonzalez R, McArthur GA Hutson TE, Moschos SJ, Flaherty KT, Kim KB, Weber JS, Hersey P, Long GV, Lawrence D, Ott PA, Amaravadi RK, Lewis KD, Puzanov I, Lo Roger S, Koehler A, Kockx M, Spleiss O, Schell-Steven A, Gilbert HN, Cockey L, Bollag G, Lee RJ, Joe AK, Sosman JA and Ribas A: Pharmacodynamic effects and mechanisms of resistance to vemurafenib in patients with metastatic melanoma. J Clin Oncol 31: 1767-1774, 2013.

44. Hauschild A, Grob J, Demidov LV, Jouary T, Gutzmer R, Millward M, Rutkowski P, Blank CU, Miller WH Jr, Kaempgen E, Martín-Algarra S, Karaszewska B, Mauch C, Chiarion-Sileni V, Martin A, Swann S, Haney P, Mirakhur B, Guckert ME, Goodman V and Chapman PB: Dabrafenib in BRAF-mutated metastatic melanoma: a multicentre, open-label, phase 3 randomised controlled trial. Lancet 380: 358-365, 2012.

45. Long GV, Trefzer U, Davies MA, Kefford RF, Ascierto PA, Chapman PB, Puzanov I, Hauschild A, Robert C, Algazi A, Mortier L, Tawbi H, Wilhelm T, Zimmer L, Switzky J, Swann S, Martin A, Guckert M, Goodman V, Streit M, Kirkwood JM and Schadendorf D: Dabrafenib in patients with Val600Glu or Val600Lys BRAF-mutant melanoma metastatic to the brain (BREAK-MB): a multicentre, open-label, phase 2 trial. Lancet Oncol 13: 1087-1095, 2012.

46. Ascierto PA, Minor D, Ribas A, Lebbe C, O'Hagan A, Arya N, Guckert M, Schadendorf D, Kefford RF, Grob J, Hamid O, Amaravadi R, Simeone E, Wilhelm T, Kim KB, Long GV, Martin A, Mazumdar J, Goodman VL and Trefzer U: Phase II trial (BREAK-2) of the BRAF inhibitor dabrafenib (GSK2118436) in patients with metastatic melanoma. J Clin Oncol 31: 3205-3211, 2013.

47. Falchook GS, Long GV, Kurzrock R, Kim KB, Arkenau TH, Brown MP, Hamid O, Infante JR, Millward M, Pavlick AC, O'Day SJ, Blackman SC, Curtis CM, Lebowitz P, Ma B, Ouellet D and Kefford RF: Dabrafenib in patients with melanoma, untreated brain metastases, and other solid tumours: a phase 1 dose-escalation trial. Lancet 379: 1893-1901, 2012.

48. Trefzer U, Minor D, Ribas A, Lebbe C, Siegfried A, Arya N, Guckert M, Schadendorf D, Kefford R, Grob JJ, Hamid O, Amaravadi R, Simeone E, Wilhelm T, Kim K, Goodman V and Ascierto PA: BREAK-2: a Phase IIA trial of the selective BRAF kinase inhibitor GSK2118436 in patients with BRAF mutationpositive (V600E/K) metastatic melanoma. Pigm Cell Melanoma R 24: 1020, 2011.

49. Gray-Schopfer V, Wellbrock $\mathrm{C}$ and Marais R: Melanoma biology and new targeted therapy. Nature 445: 851-857, 2007.

50. Johnson DB and Sosman JA: Update on the targeted therapy of melanoma. Curr Treat Options Oncol 14: 280-292, 2013.

51. Chang L and Karin M: Mammalian MAP kinase signalling cascades. Nature 410: 37-40, 2001.

52. Thompson $\mathrm{N}$ and Lyons $\mathrm{J}$ : Recent progress in targeting the Raf/ MEK/ERK pathway with inhibitors in cancer drug discovery. Curr Opin Pharmacol 5: 350-356, 2005.

53. Catalanotti F, Solit DB, Pulitzer MP, Berger MF, Scott SN, Iyriboz T, Lacouture ME, Panageas KS, Wolchok JD, Carvajal RD, Schwartz GK, Rosen N, Chapman PB: Phase II trial of MEK inhibitor selumetinib (AZD6244, ARRY-142886) in patients with BRAFV600E/K-mutated melanoma. Clin Cancer Res 19: 2257-2264, 2013

54. Flaherty KT, Robert C, Hersey P, Nathan P, Garbe C, Milhem M, Demidov LV, Hassel JC, Rutkowski P, Mohr P, Dummer R, Trefzer U, Larkin JM, Utikal J, Dreno B, Nyakas M, Middleton MR, Becker JC, Casey M, Sherman LJ, Wu FS, Ouellet D, Martin AM, Patel K and Schadendorf D: Improved survival with MEK inhibition in BRAF-mutated melanoma. N Engl J Med 367: 107-114, 2012. 
55. Byron SA, Loch DC, Wellens CL, Wortmann A, Wu J, Wang J, Nomoto K and Pollock PM: Sensitivity to the MEK inhibitor E6201 in melanoma cells is associated with mutant BRAF and wildtype PTEN status. Mol Cancer 11: 75, 2012.

56. Falchook GS, Lewis KD, Infante JR, Gordon MS, Vogelzang NJ, De Marini DJ, Sun P, Moy C, Szabo SA, Roadcap LT, Peddareddigari VG, Lebowitz PF, Le NT, Burris HA III, Messersmith WA, O'Dwyer PJ, Kim KB, Flaherty K, Bendell JC, Gonzalez R, Kurzrock R and Fecher LA: Activity of the oral MEK inhibitor trametinib in patients with advanced melanoma: a phase 1 dose-escalation trial. Lancet Oncol 13: 782-789, 2012.

57. Yamaguchi T, Kakefuda R, Tajima N, Sowa Y and Sakai T: Antitumor activities of JTP-74057 (GSK1120212), a novel MEK1/2 inhibitor, on colorectal cancer cell lines in vitro and in vivo. Int $\mathbf{J}$ Oncol 39: 23-31, 2011.

58. Gilmartin AG, Bleam MR, Groy A, Moss KG, Minthorn EA, Kulkarni SG, Rominger CM, Erskine S, Fisher KE, Yang J, Zappacosta F, Annan R, Sutton D and Laquerre SG: GSK1120212 (JTP-74057) is an inhibitor of MEK activity and activation with favorable pharmacokinetic properties for sustained in vivo pathway inhibition. Clin Cancer Res 17: 989-1000, 2011.

59. Akinleye A, Furqan M, Mukhi N, Ravella P and Liu D: MEK and the inhibitors: from bench to bedside. J Hematol Oncol 6: 27 , 2013.

60. Robert C, Flaherty KT, Hersey P, Nathan P, Garbe C, Milhem MM, Demidov LV, Hassel JC, Rutkowski P, Mohr P, Dummer R, Trefzer U, Larkin JMG, Utikal J, Casey M, Sherman LJ, Crist WA, Wu FS, Patel K and Schadendorf D: METRIC phase III study: efficacy of trametinib (T), a potent and selective MEK inhibitor (MEKi), in progression-free survival (PFS) and overall survival (OS), compared with chemotherapy (C) in patients (pts) with BRAF V600E/K mutant advanced or metastatic melanoma (MM) J Clin Oncol 30 (Suppl): abs. LBA8509, 2012.

61. Klinac D, Gray ES, Millward M and Ziman M: Advances in personalized targeted treatment of metastatic melanoma and non-invasive tumor monitoring. Front Oncol 3: 54, 2013.

62. Kim KB, Lewis K, Pavlick A, Infante JR, Ribas A, Sosman JA, Fecher LA, Millward M, McArthur GA, Hwu P, Gonzalez R, Ott PA, Long G, Gardner OS, Ouellet D, Xu Y, De Marini DJ, Le N,Patel K and Kefford R: A phase II study of the MEK1/MEK2 inhibitor GSK1120212 in metastatic BRAF-V600E or K mutant cutaneous melanoma patients previously treated with or without a BRAF inhibitor. International Melanoma Congress. Pigment Cell Res 24: 990-1075, 2011.

63. Ikenoue T, Kanai F, Hikiba Y, Obata T, Tanaka Y, Imamura J, Ohta M, Jazag A, Guleng B, Tateishi K, Asaoka Y, Matsumura M, Kawabe T and Omata M: Functional analysis of PIK3CA gene mutations in human colorectal cancer. Cancer Res 65: 4562-4567, 2005.

64. Isakoff SJ, Engelman JA, Irie HY, Luo J, Brachmann SM Pearline RV, Cantley LC and Brugge JS: Breast cancer-associated PIK3CA mutations are oncogenic in mammary epithelial cells Cancer Res 65: 10992-11000, 2005.

65. Zhao JJ, Liu Z, Wang L, Shin E, Loda MF and Roberts TM: The oncogenic properties of mutant p110alpha and p110beta phosphatidylinositol 3-kinases in human mammary epithelial cells. Proc Natl Acad Sci USA 102: 18443-18448, 2005.

66. Janku F, Wheler JJ, Naing A, Stepanek VM, Falchook GS, Fu S, Garrido-Laguna I, Tsimberidou AM, Piha-Paul SA, Moulder SL, Lee JJ, Luthra R, David SH and Kurzrock R: PIK3CA mutations in advanced cancers: characteristics and outcomes. Oncotarget 3 : 1566-1575, 2012

67. Zhao L and Vogt PK: Class I PI3K in oncogenic cellular transformation. Oncogene 27: 5486-5496, 2008.

68. Ligresti G, Militello L, Steelman LS, Cavallaro A, Basile F, Nicoletti F, Stivala F, McCubrey JA and Libra M: PIK3CA mutations in human solid tumors. Role in sensitivity to various therapeutic approaches. Cell Cycle 8: 1352-1358, 2009.

69. Hafsi S, Pezzino FM, Candido S, Ligresti G, Spandidos DA, Soua Z, McCubrey JA, Travali S and Libra M: Gene alterations in the PI3K/PTEN/AKT pathway as a mechanism of drugresistance. Int J Oncol 40: 639-644, 2011.

70. Mendoza MC, ErEE and Blenis J: The Ras-ERK and PI3KmTOR pathways: cross-talk and compensation. Trends Biochem Sci 36 320-328, 2011

71. Stahl JM, Sharma A, Cheung M, Zimmerman M, Cheng JQ, Bosenberg MW, Kester M, Sandirasegarane L and Robertson GP: Deregulated Akt3 activity promotes development of malignant melanoma. Cancer Res 64: 7002-7010, 2004.
72. MeierF, Schittek B, Busch S, Garbe C, Smalley K, Satyamoorthy K, Li G and Herlyn M: The RAS/RAF/MEK/ERK and PI3K/AKT signaling pathways present molecular targets for the effective treatment of advanced melanoma. Front Biosci 10: 2986-3001, 2005.

73. Russo AE, Torrisi E, Bevelacqua Y, Perrotta R, Libra M, McCubrey JA, Spandidos DA, Stivala F and Malaponte G: Melanoma: molecular pathogenesis and emerging target therapies (Review). Int J Oncol 34: 1481-1489, 2009.

74. Brana I and Siu LL: Clinical development of phosphatidylinositol 3-kinase inhibitors for cancer treatment. BMC Med 10: 161, 2012.

75. Ogita S and Lorusso P: Targeting phosphatidylinositol 3 kinase (PI3K)-Akt beyond rapalogs. Target Oncol 6: 103-117, 2011.

76. Huang A, Fritsch C, Wilson C, Reddy A, Liu M, Lehar J, Quadt C, Hofmann F and Schlegel R: Single agent activity of PIK3CA inhibitor BYL719 in a broad cancer cell line panel. Proceedings of the 103rd Annual Meeting of the American Association for Cancer Research; Chicago, IL, Philadelphia, PA. Am Assoc Cancer Res abs. 3749, 2012.

77. Jessen K, Kessler L, Kucharski J, Guo X, Staunton J, Janes M, Elia M, Banerjee U, Lan L, Wang S, Stewart J, Luzader A, Darjania L, Li L, Chan K, Martin M, Ren P, Rommel C and Liu Y: A potent and selective PI3K inhibitor, INK1117, targets human cancers harboring oncogenic PIK3CA mutations. AACRNCI-EORTC International Conference: Molecular Targets and Cancer Therapeutics San Francisco, CA, Philadelphia, PA. Am Assoc Cancer Res 10: abs. A171, 2011.

78. Britten CD: PI3K and MEK inhibitor combinations: examining the evidence in selected tumor types. Cancer Chemother Pharmacol 71: 1395-1409, 2013

79. Liu P, Cheng H, Roberts TM and Zhao JJ: Targeting the phosphoinositide 3-kinase pathway in cancer. Nat Rev Drug Discov 8: 627-644, 2009.

80. Markman B, Dienstmann R and Tabernero J: Targeting the PI3K/ Akt/mTOR pathway - beyond rapalogs. Oncotarget 1: 530-543, 2010.

81. Mansh M: Ipilimumab and cancer immunotherapy: a new hope for advanced stage melanoma. Yale J Biol Med 84: 381-389, 2011.

82. Sondak VK, Smalley KS, Kudchadkar R, Grippon S and Kirkpatrick P: Ipilimumab. Nat Rev Drug Discov 10: 411-412, 2011.

83. Fellner C: Ipilimumab (Yervoy) prolongs survival in advanced melanoma. Drug Forecast 37: 503-530, 2012.

84. Tjin EP, Konijnenberg D, Krebbers G, Mallo H, Drijfhout JW, Franken KL, van der Horst CM, Bos JD, Nieweg OE, Kroon BB, Haanen JB, Melief CJ, Vyth-Dreese FA and Luiten RM: T cell immune function in tumor, skin, and peripheral blood of advance stage melanoma patients: implications for immunotherapy. Clin Cancer Res 17: 5736-5747, 2011.

85. Levings MK, Sangregorio R and Roncarolo MG: Human cd25(+) $\mathrm{cd} 4(+) \mathrm{t}$ regulatory cells suppress naive and memory $\mathrm{T}$ cell proliferation and can be expanded in vitro without loss of function. J Exp Med 193: 1295-1302, 2001

86. Melero I, Hervas-Stubbs S, Glennie M, Pardoll DM and Chen L: Immunostimulatory monoclonal antibodies for cancer therapy. Nat Rev Cancer 7: 95-106, 2007.

87. Agarwala SS: Current systemic therapy for metastatic melanoma. Expert Rev Anticancer Ther 9: 587-595, 2009.

88. Kirkwood JM, Tarhini AA, Panelli MC, Moschos SJ, Zarour HM, Butterfield LH and Gogas HJ: Next generation of immunotherapy for melanoma. J Clin Oncol 26: 3445-3455, 2008.

89. Antony GK and Dudek AZ: Interleukin 2 in cancer therapy. Curr Med Chem 17: 3297-3302, 2010.

90. Chmielowski B: Ipilimumab: a first-in-class T-cell potentiator for metastatic melanoma. J Skin Cancer 2013: 423829, 2013.

91. Hodi FS, O'Day SJ, McDermott DF, Weber RW, Sosman JA, Haanen JB, Gonzalez R, Robert C, Schadendorf D, Hassel JC, Akerley W, van den Eertwegh AJ, Lutzky J, Lorigan P, Vaubel JM, Linette GP, Hogg D, Ottensmeier CH, Lebbé C, Peschel C, Quirt I, Clark JI, Wolchok JD, Weber JS, Tian J, Yellin MJ, Nichol GM, Hoos A and Urba WJ: Improved survival with ipilimumab in patients with metastatic melanoma. N Engl J Med 363: 211-223, 2010.

92. Robert $\mathrm{C}$ and Ghiringhelli $\mathrm{F}$ : What is the role of cytotoxic T lymphocyte-associated antigen 4 blockade in patients with metastatic melanoma? Oncologist 14: 848-861, 2009.

93. Hwu P: Treating cancer by targeting the immune system. N Engl J Med 363: 779-781, 2010. 
94. Wolchok JD, Neyns B, Linette G, Negrier S, Lutzky J, Thomas L, Waterfield W, Schadendorf D, Smylie M, Guthrie T Jr, Grob JJ, Chesney J, Chin K, Chen K, Hoos A, O'Day SJ and Lebbé C: Ipilimumab monotherapy in patients with pretreated advanced melanoma: a randomised, double-blind, multicentre, phase 2, dose-ranging study. Lancet Oncol 11: 155-164, 2010.

95. Lipson EJ and Drake CG: Ipilimumab: an anti-CTLA-4 antibody for metastatic melanoma. Clin Cancer Res 17: 6958-6962, 2011.

96. Di Giacomo AM, Calabrò L, Danielli R, Fonsatti E, Bertocci E, Pesce I, Fazio C, Cutaia O, Giannarelli D, Miracco C, Biagioli M, Altomonte $\mathrm{M}$ and Maio $\mathrm{M}$ : Long-term survival and immunological parameters in metastatic melanoma patients who responded to ipilimumab $10 \mathrm{mg} / \mathrm{kg}$ within an expanded access programme. Cancer Immunol Immunother 62: 1021-1028, 2013.

97. Feng Y, Roy A, Masson E, Chen T, Humphrey R and Weber JS: Exposure-response relationships of the efficacy and safety of ipilimumab in patients with advanced melanoma. Clin Cancer Res 19: 3977-3986, 2013

98. Melero I, Grimaldi AM, Perez-Gracia JL and Ascierto PA Clinical development of immunostimulatory monoclonal antibodies and opportunities for combination. Clin Cancer Res 19: 997-1008, 2013

99. Topalian SL, Hodi FS, Brahmer JR, Gettinger SN, Smith DC, McDermott DF, Powderly JD, Carvajal RD, Sosman JA, Atkins MB, Leming PD, Spigel DR, Antonia SJ, Horn L, Drake CG, Pardoll DM, Chen L, Sharfman WH, Anders RA, Taube JM, McMiller TL, Xu H, Korman AJ, Jure-Kunkel M, Agrawal S, McDonald D, Kollia GD, Gupta A, Wigginton JM and Sznol M: Safety, activity, and immune correlates of anti-PD-1 antibody in cancer. N Engl J Med 366: 2443-2454, 2012.

100. Shahabi V, Whitney G, Hamid O, Schmidt H, Chasalow SD, Alaparthy S and Jackson JR: Assessment of association between BRAF-V600E mutation status in melanomas and clinical response to ipilimumab. Cancer Immunol Immunother 61: 733-737, 2012.

101. Davar D, Tarhini AA and Kirkwood JM: Adjuvant immunotherapy of melanoma and development of new approaches using the neoadjuvant approach. Clin Dermatol 31: 237-250, 2013.

102. Lo RS: Combinatorial therapies to overcome B-RAF inhibitor resistance in melanomas. Pharmacogenomics 13: 125-128, 2012.

103. Infante JR, Falchook GS, Lawrence DP, Weber JS, Kefford RF, Bendell JC, Kurzrock R, Shapiro G, Kudchadkar RR, Long GV, Burris HA, Kim KB, Clements A, Peng S, Yi B, Allred AJ, Ouellet D, Patel K, Lebowitz PF and Flaherty KT: Phase I/II study to assess safety, pharmacokinetics, and efficacy of the oral MEK $1 / 2$ inhibitor GSK1120212 (GSK212) dosed in combination with the oral BRAF inhibitor GSK2118436 (GSK436). J Clin Oncol 29 (Suppl): abs. CRA8503, 2011.
104. Weber JS, Flaherty KT, Infante JR, Falchook GS, Kefford R, Daud A, Hamid O, Gonzalez R, Kudchadkar RR, Lawrence DP, Burris HA, Long GV, Algazi AP, Lewis KD, Kim KB, Puzanov I, Sun P, Little SM, Patel K and Sosman JA: Updated safety and efficacy results from a phase I/II study of the oral BRAF inhibitor dabrafenib (GSK2118436) combined with the oral MEK 1/2 inhibitor trametinib (GSK1120212) in patients with BRAFi-naïve metastatic melanoma. J Clin Oncol 30 (Suppl): abs. 8510, 2012.

105. Curti BD and Urba WJ: Integrating new therapies in the treatment of advanced melanoma. PhD Current Treatment Options in Oncology. Skin Cancer 13: 327-339, 2012.

106. Ascierto PA, Simeone E, Giannarelli D, Grimaldi AM, Romano A and Mozzillo N: Sequencing of BRAF inhibitors and ipilimumab in patients with metastatic melanoma: a possible algorithm for clinical use. J Transl Med 10: 107, 2012

107. Comin-Anduix B, Chodon T, Sazegar H, Matsunaga D, Mock S, Jalil J, Escuin-Ordinas H, Chmielowski B, Koya RC and Ribas A: The oncogenic BRAF kinase inhibitor PLX4032/RG7204 does not affect the viability or function of human lymphocytes across a wide range of concentrations. Clin Cancer Res 16: 6040-6048, 2010.

108. Wargo JA, Cogdill A, Dang P, Gupta R, Piris A, Boni A, Garber HR, Ott H, Newton LP, Flaherty KT, Lawrence DP, Tsao $\mathrm{H}$ and Fisher DE: Treatment with a selective inhibitor of BRAFV600E increases melanocyte antigen expression and CD8 $\mathrm{T}$ cell infiltrate in tumors of patients with metastatic melanoma. Cancer Res 71: abs. 95, 2011.

109. Wilmott JS, Long GV, Howle JR, Haydu LE, Sharma RN, Thompson JF, Kefford RF, Hersey P and Scolyer RA: Selective BRAF inhibitors induce marked T-cell infiltration into human metastatic melanoma. Clin Cancer Res 18: 1386-1394, 2012.

110. Mijatovic S, Maksimovic-Ivanica D, Mojic M, Malaponte G, Libra M, Cardile V, Miljkovic D, Harhaji L, Dabideen D, Cheng KF, Bevelacqua Y, Donia M, Garotta G, Al-Abed Y, Stosic-Grujicic S and Nicoletti F: Novel nitric oxide-donating compound (S,R)-3-phenyl-4,5-dihydro-5-isoxazole acetic acidnitric oxide (GIT-27NO) induces p53 mediated apoptosis in human A375 melanoma cells. Nitric Oxide 19: 177-183, 2008.

111. Donia M, Mangano K, Fagone P, De Pasquale R, Dinotta F, Coco M, Padron J, Al-Abed Y, Lombardo GA, MaksimovicIvanic D, Mijatovic S, Zocca M, Perciavalle V, Stosic-Grujicic S and Nicoletti F: Unique antineoplastic profile of Saquinavir-NO, a novel NO-derivative of the protease inhibitor Saquinavir, on the in vitro and in vivo tumor formation of A375 human melanoma cells. Oncol Rep 28: 682-688, 2012. 